\title{
The adaptation of scientific reasoning of prospective teachers for primary education in the perspective of civic science
}

\author{
Yayuk Hidayah ${ }^{1}$, Dinie Anggraeni Dewi ${ }^{2}$, Meiwatizal Trihastuti ${ }^{3}$ \\ ${ }^{1}$ Primary School Teacher Education Study Program, Universitas Ahmad Dahlan, Yogyakarta, Indonesia \\ 2 Primary School Teacher Education Study Program, Universitas Pendidikan Indonesia, Bandung, Indonesia \\ ${ }^{3}$ Pancasila and Civic Education Study Program, STKIP Pasundan, Cimahi, Indonesia
}

\begin{abstract}
This article aims to determine the adaptation of prospective elementary school teachers' scientific reasoning from a civic science perspective through seminar courses on educational problems in elementary schools. The issue of distance learning during the Corona Virus Disease (Covid) 19 pandemics in Indonesia has led to various highlights and analyzes. The learning scheme's quality and learning scheme are among the most popular questions in this learning scheme. This research uses a case study with a qualitative approach with data collection using interviews, observation, documentation, and literature studies. The results showed that the adaptation of the scientific reasoning of prospective elementary school teachers in a civic science perspective through the Seminar on Educational Problems in Primary Schools has several characteristics, that is: 1) educational problems in primary schools captured by dominant students in technological literacy, 2) study of educational problems in schools fundamental relates to the realization of smart and good citizens that reflected in attitudes and behavior in the Covid-19 pandemic situation, and 3) there is character building in the adaptation of scientific reasoning in the civic science perspective. Therefore, the research expects to have implications in developing knowledge of civic education, especially in elementary school, which aims to strengthen the study of civic education.
\end{abstract}

Article History:

Submitted

Revision

: 24-12-2020

Accepted

06-01-2021

10-01-2021

Keywords:

respective elementary school

teachers; civic science; scientific

reasoning; critical thinking

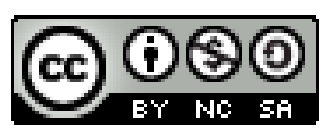

\section{Cite in APA ${ }^{\text {th }}$ :}

Hidayah, Y., Dewi, D. A., \& Trihastuti, M. (2021). The adaptation of scientific reasoning of prospective teachers for primary education in the perspective of civic science. Jurnal Civics: Media Kajian Kewarganegaraan, 18(1), 1-9. https://doi.org/10.21831/JC.V18I1.36916

\section{Introduction}

The existence of problems in life requires humans to provide solutions to problems based on logical arguments. Browder et al. (2018) argue that the current education policy requires problem-solving skills. Meanwhile, Nagy Kem (2016) emphasizes that students should be challenged to practice what only they can solve independently. Therefore, having logical and critical thinking in social reality is essential for every individual, especially young intellectuals. In line with this, Naini (2012) argues that it is not uncommon to show misconceptions about science and knowledge in academic conversations.

Science currently places a greater emphasis on building real empirical words (Losch, 2018). It is appropriate for students to learn to condition the problems to explore these problems from various perspectives. Morin et al. (2017) state that an effective learning strategy is useful for increasing students' ability to use cognitive strategies.

In various forms of learning, the adaptation of scientific reasoning for students requires preparation and reasonable arguments. Mueller et al. (2020) state that scientific reasoning and 
problem-solving are essential skills for students nowadays. Schiefer et al. (2019) emphasize that scientific reasoning abilities have developed since students made sense of the world around them. Therefore, when a student accustomed to critical thinking, he will have an outstanding, systematic, and right mindset

During the Covid-19 in Indonesia, learning has transformed into an online learning scheme. Suharwoto (2020) states that online learning during the Covid 19 pandemic in Indonesia is maturing. In this situation, various problems regarding online learning schemes' effectiveness have been questionable, particularly for students and prospective elementary school teachers who are taking seminars on educational problems in elementary schools in the 2019/2020 academic year at Ahmad Dahlan University, Yogyakarta.

The seminar course on Educational Problems in Elementary School is a subject that requires students to have several problems to be disseminated and continued as a thesis research project. Scientific reasoning for prospective elementary school teachers in the seminar course must also be considered during remote learning because critical thinking is important (Shaw, 2014). Roohr and Burkander (2020) also expressed the same opinion that critical thinking can improve students' performance in their particular fields.

Based on the interview results with students who apply for the seminar course on educational problems in elementary school in the academic year 2019/2020 at Ahmad Dahlan University, online learning has made thinking harder to catch problems. Another student also expressed the same evidence that online learning presented various challenges in capturing educational problems in elementary school.

Besides, based on some literature analyses were indicating scientific reasoning. First, scientific reasoning is a rapidly developing research field with a solid foundation in cognitive psychology and science. In recent years, a new professional society formed to facilitate this integrative and interdisciplinary approach to science's psychology with its regular journals and professional meetings (Dunbar \& Klahr, 2012). Second, scientific reasoning refers to the mental processes used when reasoning about the content of science (e.g., forces in physics), engaging in typical scientific activities (e.g., designing experiments), or particular types of reasoning that are often used in science (e.g., concluding that there are planets outside of Pluto). Scientific reasoning involves a diversity of general-purpose cognitive operations that humans apply in non-scientific tasks such as induction, deduction, analysis, problem-solving, and causal reasoning (Dunbar \& Fugelsang, 2005). Third, an integrative review of children's scientific reasoning has shown that metacognitive skills help understand cognitive development and apply subsequent findings to formal and informal educational settings (Zimmerman, 2005).

The fourth, regarding the development of scientific reasoning, the current research is the deficit. It addresses five aspects of how scientific research have expanded within a conceptual framework with three epistemic modes (advanced theory building on natural and social phenomena, artifact-centered scientific reasoning, and science-based reasoning in practice) and eight epistemic activities (problem identification, questioning, hypothesis generation, construction and re-design of artifacts, evidence generation), evaluation of evidence, drawing conclusion and communication and researching scientific reasoning and results). We further propose to address the domain specificity and domain generality of scientific reasoning and argumentation as an approach to mediation (Fischer et al., 2014).

The fifth, the introduction to the development of scientific reasoning skills, have taken a more integrated approach and used strategies in a sufficiently complex domain to examine the 
conditions under which a subject theory (or prior knowledge) affects experimentation, evidence evaluation, and revision of beliefs (Zimmerman, 2000).

Viewed from the perspective of civic science, the adaptation of scientific reasoning is a form of normative and epistemological challenge in the study of Citizenship Education. Following Bäckstrand (2003) opinion, civic science in the global environment's scope is articulated in international relations, science studies, democracy, and sustainable science. Makuch and Aczel (2020) also emphasize that civic education's development contributes to the discourse on social goodness and social justice explicitly in the civic project.

The adaptation of scientific reasoning for remote learning in the seminar course in elementary school illustrates a holistic learning form evidenced by students who develop their cognitive abilities and gradually develop affective and psychomotor. A holistic learning pattern becomes a medium to develop civic disposition so that civic competence will be better. Indeed, this is one of Citizenship Education's goals that the essence of Citizenship Education is political democracy education, which brings positive benefits to students in critical thinking, attitude, and acting according to Pancasila and the 1945 Constitution (Somantri, 2001).

This study aims to determine how to adapt the scientific reasoning of prospective elementary school teachers from a civic science perspective through a seminar on educational problems in elementary schools. Therefore, to achieve the goal, this study's problem is how to adapt the scientific reasoning of prospective elementary school teachers in a civic science perspective through a seminar on educational problems in elementary schools? Researchers hope that the theoretical benefits of research can renew civic science thinking to study educational problems in elementary schools. While practically the research results hopefully will contribute to the development of a civic science perspective on educational problems in elementary schools.

\section{Method}

This study was descriptive qualitative research. This study's scope was to adapt the scientific reasoning of prospective elementary school teachers from a civic science perspective. The research was initiated by conducting a preliminary study on the adaptation pattern of scientific reasoning by prospective elementary school teachers through a seminar on educational problems in elementary schools in the 2019/2020 academic year at Ahmad Dahlan University, Yogyakarta, from 21 September 2020 to 15 October 2020 (during distance learning).

In this study, the subjects were PGSD UAD students who taught seminars on educational problems in elementary schools in the 2019/2020 odd school year at Ahmad Dahlan University, class F1, totaling 28 people. The research subject's determination was done by purposive sampling because, in qualitative research, there was no research sample. Creswell (2012) emphasized no research subjects in qualitative research, but there were samples with purposive sampling. Therefore, researchers used purposive sampling in determining the subject in this study. The research location was an online class seminar on educational problems in elementary schools in the 2019/2020 academic year at Ahmad Dahlan University, Yogyakarta.

\section{Results and Discussion}

In this study, researchers found several findings, which researchers will discuss in depth. The researcher then divided it into several subsections to quickly achieve the discussion's readability to facilitate its depth. Following this, the researchers discuss the research findings in the form of paragraphs and sub-chapter titles. In simple terms, the research findings regarding the adaptation of scientific reasoning for primary school teacher candidates in the perspective of civic science can the researchers describe as follows. 
Yayuk Hidayah, Dinie Anggaraeni Dewie, Meiwatizal Trihastuti. The adaptation of scientific reasoning of prospective teachers for primary education in the perspective of civic science

Figure 1

Adaptation of Scientific Reasoning for Primary School Teacher Candidates in the Perspective of Civic Science

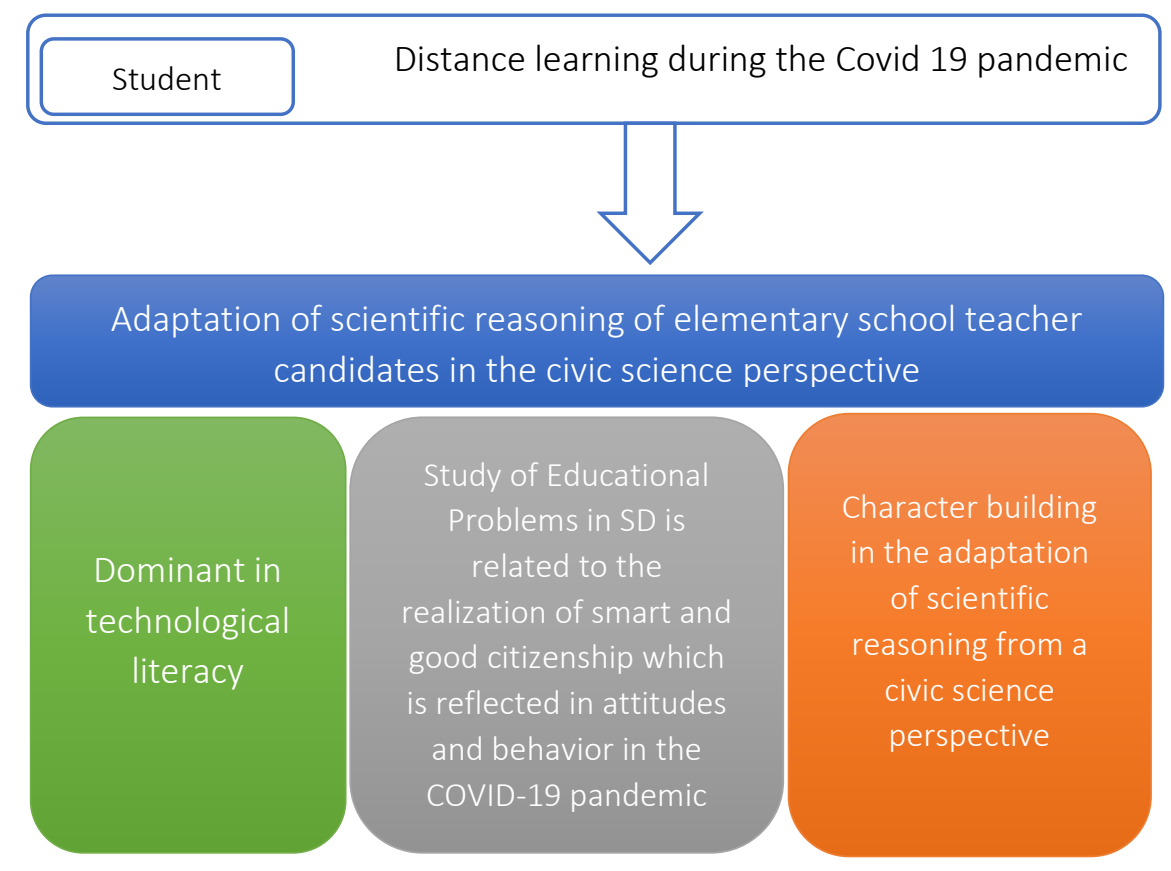

\section{Technology Literacy as Elementary School Education Problems Of Students}

Based on the study results on the adaptation of scientific reasoning of prospective elementary school teachers in civic science through a seminar on educational problems in elementary schools, the problems of education in elementary school were undertaken by most students in technological literacy. This evidence was based on a learning situation during the pandemic that used technology or online media.

We realized that the online learning scheme had exploited a lot of technological devices. The use of technological devices in learning during the Covid-19 Pandemic had provided broad access for students. Dhull and Sakhshi (2017) argue that online learning is considered an advantage due to its accessibility, personalized learning, and developing cognitive abilities. Besides, Glenn (2018) mentions that online learning for students provides motivation to accept responsibility in a virtual classroom platform actively.

The dominant technological literacy in the seminar course on elementary school educational problems is a good learning process. In the same perspective, Turner and Katic (2009) argue that many forms of technological communication in the learning environment have led to new approaches to learning that are preferably more naturalistic and authentic.

Technological literacy in the seminar course has also provided a broad and deep reflection that learning also requires media in its process. Dale and Pymm (2009) have the same perspective that using technology as part of a new type of learning media has offered new opportunities to enhance students' learning experiences. 
Figure 2

Students were Making Presentations through Google Meet

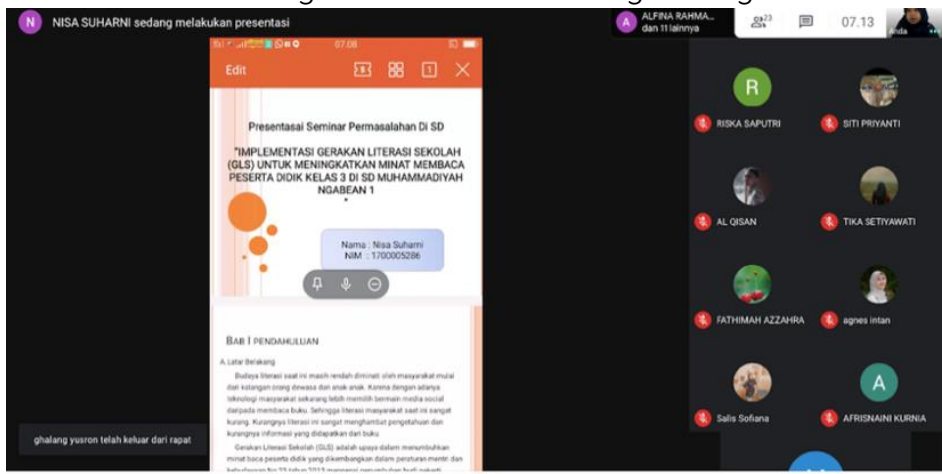

Furthermore, the study results also showed that the adaptation of scientific reasoning in technological literacy developed in accessing, communicating, and disseminating information appropriately. These results are in line with Bugliarello's study that technological literacy means far more than just the ability to use computers and understand, create, and develop technology and its impact on society, individuals, and the environment (2000).

The existence of technological literacy in the adaptation of prospective elementary school teachers' scientific reasoning from civic science is a form of new habits towards technology. Relevant to this, Gars and Skov (2016) clarify that technology creates new habits and routines for individuals. Technological literacy implies the active use of technology in society. In this situation, the next step is to provide an understanding of the importance of technological literacy.

\section{Study of Educational Problems in Elementary Schools Related to The Realization of Smart and Good Citizenship Reflected In Attitude And Behavior}

Based on the study results, the study of educational problems in elementary school was related to the realization of smart and good citizenship reflected in attitude and behavior during the Covid-19 pandemic situation. Budimansyah (2012) confirms that establishing responsible and good citizens is the primary concern in various situations.

The manifestation of smart and good citizenship reflected in the adaptation of students' scientific reasoning in attitude and behavior had shown the more factual and not abstract form of thinking. Relevant to this, Huber and Kuncel (2016) state that the meta-analysis synthesizes gains in critical thinking skills and student attitude dispositions through critical thinking skills substantially in the college experience.

Figure 3

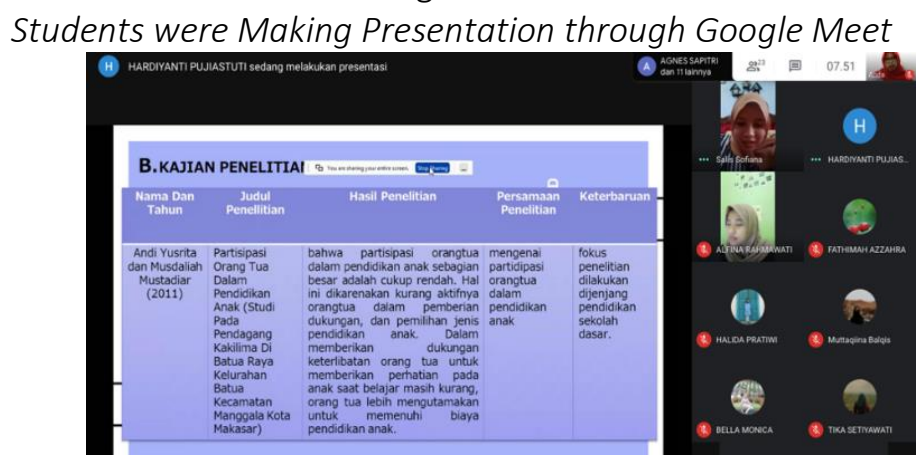

Furthermore, it was also found that the study of educational problems in elementary school led to an awareness of attitudes with the adaptation of the "new normal" during the Covid-19 pandemic, such as the identification of problems in the analysis of student learning attitudes, analysis of teacher readiness in online learning, analysis of students' readiness in online learning, 
and the readiness of parents for online learning. For Waks (2018), the internet and digital tools can design new virtual study spaces and learning activities.

Smart and good citizenship through a study of educational problems in elementary school during the Covid-19 pandemic often reflects the ability to use critical thinking skills reflected in attitudes and behavior during the Covid-19 pandemic situation. Researchers consider this it cannot be denied that the pandemic situation has changed some of the human lifeways (Asante \& Mills, 2020). It is also stated that the socio-economic impact of the Covid 19 pandemic is in rising food prices, economic difficulties due to lockdown directives, and vital relocation to enforce social distancing.

The implementation of several new habits in the "new normal" provides a study of educational problems in elementary school along with the implementation of the prevention of Covid-19. In connection with the realization of smart and good citizenship, this is certainly an effective measure that shows that they are thinking about the research's implications. This is in line with McPhillips' statement that a particular contribution we can make is to support ideas nurtured through imaginative and visionary thinking (2005).

A study of educational problems in elementary school is also related to smart and good citizenship as a character building. It is in line with Lickona's opinion that the concept of character education is through fostering education to shape one's personality characteristics (2009). To realize smart and good citizenship is indeed not an easy thing, but by understanding how the current situation and conditions, we will find ways to find solutions in the embodiment of smart and good citizenship in Indonesia.

\section{Character Building in The Adaptation of Scientific Reasoning in The Perspective Of Civic Science}

Based on the study results, there was character building in the adaptation of scientific reasoning from civic science perspective. Lickona (2015) states that broad character education is deliberate in the manifestation of goodness to have a good impact on oneself and society. Besides, character building in the adaptation of scientific reasoning includes responsibility, discipline, and criticism.

The fostering of responsibility in the adaptation of scientific reasoning in the civic science perspective encourages students to take a position by the practice of lectures in the seminar. In support of these arguments, Schrempf-Stirling and Palazzov (2013) stated the meaning of expanding responsibility regarding expanding the scope of responsibility for rights. Secondly, there is a broader expansion of responsibility to the entire individual authority, and lastly, the responsibility creates an evolution of practice (Schrempf-Stirling \& Palazzo, 2013).

The development of the positive character of responsibility will gradually foster students to behave following moral values and norms in society. Svensson et al. (2016) state that individual changes are associated with changes in moral values, anticipated shame, and guilt. So, in terms of the character of responsibility, the emphasis is on practical lectures in elementary education seminars that develop responsibility morality for students.

It was more than a hundred years ago that Emile Durkheim argued that normative learning of self-interest has been "subordinated" to the norm of social solidarity (Vila-Henninger, 2016). Based on the results, the development of disciplinary character in the adaptation of scientific reasoning from the civic science perspective leads to guiding students to become obedient individuals and obey positive moral values according to their beliefs. 
The fostering of critical character in the adaptation of scientific reasoning in a civic science perspective through lectures on educational problems in elementary school seminars is evident in a critical student mindset in responding to educational problems in elementary school. According to Hwang et al. (2016), contextual differences play an important role in shaping fixed mindsets and their consequences. The existence of striking characters in the seminar course on elementary school educational problems can be considered a difference in behaving with other individuals.

\section{Conclusion}

Dominant students catch educational problems in elementary schools in technological literacy because it is influenced by online learning during the Covid-19 pandemic in Indonesia. Some studies of educational problems in elementary school are related to the realization of smart and good citizenship reflected in attitude and behavior. There is character building in the adaptation of scientific reasoning in the civic science perspective, namely the character of responsibility, discipline, and critique, Therefore, this study is expected to have implications in the development of Civics Education knowledge, especially elementary schools, which aim to strengthen the study of Citizenship Education.

\section{Acknowledgments}

The author would like to thank all the speakers in class F1 of Seminar Subject on Educational Problems in Elementary Schools who have been willing to be interviewed.

\section{References}

Asante, L. A., \& Mills, R. O. (2020). Exploring the socio-economic impact of COVID-19 pandemic in marketplaces in urban Ghana. Africa Spectrum, 55(2), 170-181. https://doi.org/10.1177/0002039720943612

Bäckstrand, K. (2003). Civic science for sustainability: Reframing the role of experts, policy-makers and citizens in environmental governance. Global Environmental Politics, 3(4), 24-41. https://doi.org/10.1162/152638003322757916

Browder, D. M., Spooner, F., Lo, Y., Saunders, A. F., Root, J. R., Ley Davis, L., \& Brosh, C. R. (2018). Teaching students with moderate intellectual disability to solve word problems. The Journal of Special Education, 51(4), 222-235. https://doi.org/10.1177/0022466917721236

Budimansyah, D. (2012). Dimensi-dimensi praktik pendidikan karakter. Widaya Aksara Press.

Bugliarello, G. (2000). Reflections on technological literacy. Bulletin of Science, Technology \& Society, 20(2), 83-89. https://doi.org/10.1177/027046760002000201

Creswell, J. W. (2012). Educational research: Planning, conducting, and evaluating quantitative and qualitative research. Pearson.

Dale, C., \& Pymm, J. M. (2009). Podagogy: The iPod as learning technology. Active Learning in Higher Education, 10(1), 84-96. https://doi.org/10.1177/1469787408100197

Dhull, I., \& Sakhshi, M. (2017). Online learning. International Education \& Research Journal, 3(8), $32-34$.

Dunbar, K. N., \& Fugelsang, J. (2005). Scientific thinking and reasoning. In The Cambridge handbook of thinking and reasoning. (hal. 705-725). Cambridge University Press.

Dunbar, K. N., \& Klahr, D. (2012). Scientific thinking and reasoning. In K. J. Holyoak \& R. G. Morrison (Ed.), The oxford handbook of thinking and reasoning (hal. 701-718). Oxford University Press. https://doi.org/10.1093/oxfordhb/9780199734689.013.0035 
Fischer, F., Kollar, I., Ufer, S., Sodian, B., Hussmann, H., Pekrun, R., Neuhaus, B., Dorner, B., Pankofer, S., Fischer, M., Strijbos, J.-W., Heene, M., \& Eberle, J. (2014). Scientific reasoning and argumentation: Advancing an interdisciplinary research agenda in education. Frontline Learning Research, 2(3), 28-45. https://doi.org/10.14786/flr.v2i2.96

Gars, U., \& Skov, H. (2016). The TECS model leads to active use of technology in home care. Nordic Journal of Nursing Research, 37(1), 51-58. https://doi.org/10.1177/2057158516662431

Glenn, C. W. (2018). Adding the human touch to asynchronous online learning. Journal of College Student Retention: Research, Theory \& Practice, 19(4), 381-393. https://doi.org/10.1177/1521025116634104

Huber, C. R., \& Kuncel, N. R. (2016). Does college teach critical thinking? A meta-analysis. Review of Educational Research, 86(2), 431-468. https://doi.org/10.3102/0034654315605917

Hwang, N., Reyes, M., \& Eccles, J. S. (2016). Who holds a fixed mindset and whom does It harm in $\begin{array}{llll}\text { mathematics? } \quad \text { Youth } \quad \text { S } & \text { 247-267). }\end{array}$ https://doi.org/10.1177/0044118X16670058

Lickona, T. (2009). Educating for character: How our schools can teach respect and responsibility. Bantam Books.

Lickona, T. (2015). Character matters; Persoalan karakter, bagaimana membantu anak mengembangkan penilaian yang baik, integritas dan kebajikan penting lainnya. Bumi Aksara.

Losch, A. (2018). Appreciating faith and culture in an age of scientific reasoning: On constructivecritical realism. Theology Today, 75(2), 154-166. https://doi.org/10.1177/0040573618783419

Makuch, K. E., \& Aczel, M. R. (2020). Eco-citizen science for social good: Promoting child wellbeing, environmental justice, and inclusion. Research on Social Work Practice, 30(2), 219232. https://doi.org/10.1177/1049731519890404

McPhillips, K. (2005). Global violence: Some thoughts on hope and change. Feminist Theology, 14(1), 25-34. https://doi.org/10.1177/0966735005057799

Morin, L. L., Watson, S. M. R., Hester, P., \& Raver, S. (2017). The use of a bar model drawing to teach word problem solving to students with mathematics difficulties. Learning Disability Quarterly, 40(2), 91-104. https://doi.org/10.1177/0731948717690116

Mueller, J. F., Taylor, H. K., Brakke, K., Drysdale, M., Kelly, K., Levine, G. M., \& Ronquillo-Adachi, J. (2020). Assessment of scientific inquiry and critical thinking: Measuring APA goal 2 student learning outcomes. Teaching of Psychology, 47(4), 274-284. https://doi.org/10.1177/0098628320945114

Nagy Kem, G. (2016). Developing problem-solving skills. Mathematics Competitions, 29, 26-40.

Naini, F. B. (2012). Black swans - The basis of scientific reasoning. Journal of Orthodontics, 39(4), 243-244. https://doi.org/10.1179/1465312512Z.00000000048

Roohr, K. C., \& Burkander, K. (2020). Exploring critical thinking as an outcome for students enrolled in community colleges. Community College Review, 48(3), 330-351. https://doi.org/10.1177/0091552120923402

Schiefer, J., Golle, J., Tibus, M., \& Oschatz, K. (2019). Scientific reasoning in elementary school children: Assessment of the inquiry cycle. Journal of Advanced Academics, 30(2), 144-177. https://doi.org/10.1177/1932202X18825152 
Schrempf-Stirling, J., \& Palazzo, G. (2013). Upstream corporate social responsibility: The evolution from contract responsibility to full producer responsibility. Business \& Society, 55(4), 491527. https://doi.org/10.1177/0007650313500233

Shaw, R. D. (2014). How critical is critical thinking? Music Educators Journal, 101(2), 65-70. https://doi.org/10.1177/0027432114544376

Somantri, M. N. (2001). Menggagas pembaharuan Pendidikan IPS. Remaja Rosdakarya dan PPs UPI.

Suharwoto, G. (2020, April 11). Pembelajaran online di tengah pandemi Covid-19, tantangan yang mendewasakan/ Pusdatin. https://pusdatin.kemdikbud.go.id/pembelajaran-online-ditengah-pandemi-covid-19-tantangan-yang-mendewasakan/

Svensson, R., Pauwels, L. J. R., Weerman, F. M., \& Bruinsma, G. J. N. (2016). Explaining individual changes in moral values and moral emotions among adolescent boys and girls: A fixedeffects analysis. European Journal of Criminology, 14(3), 290-308. https://doi.org/10.1177/1477370816649626

Turner, K. H., \& Katic, E. K. (2009). The influence of technological literacy on students' writing. Journal of Educational Computing Research, 41(3), 253-270. https://doi.org/10.2190/EC.41.3.a

Vila-Henninger, L. (2016). The moral economies of self-interest. Sociological Perspectives, 60(1), 168-185. https://doi.org/10.1177/0731121416629995

Waks, L. J. (2018). Thinking in Dewey's experimentalist education: The contribution of the internet and digital tools. ECNU Review of Education, 1(2), 1-22. https://doi.org/10.30926/ecnuroe2018010201

Zimmerman, C. (2000). The development of scientific reasoning skills. Developmental Review, 20(1), 99-149. https://doi.org/10.1006/drev.1999.0497

Zimmerman, C. (2005). The development of scientific reasoning skills: What psychologists contribute to an understanding of elementary science learning. https://www.informalscience.org/development-scientific-reasoning-skills-whatpsychologists-contribute-understanding-elementary 